\title{
Identification of Land Subsidence and Management Using Cadastral Techniques, Mining Area of Raniganj, Barddhaman District, India
}

\author{
Sonjay Mondal ${ }^{1}$, Debashish Chakravarty ${ }^{2}$, Jatisankar Bandyopadhyay ${ }^{1} \&$ Kunal Kanti Maiti ${ }^{1}$ \\ ${ }^{1}$ Department of Remote Sensing \& GIS, Vidyasagar University, Midnapore-721102, West Bengal, India \\ ${ }^{2}$ Department of Mining Engineering, Indian Institute of Technology, Kharagpur-721302, West Bengal, India \\ Correspondence: Sonjay Mondal, Department of Remote Sensing \& GIS, Vidyasagar University, West Bengal, \\ India. E-mail: sonjaymondal@gmail.com
}

Received: March 5, 2016

Accepted: March 20, 2016

Online Published: December 3, 2016

doi:10.5539/eer.v6n2p52

URL: http://dx.doi.org/10.5539/eer.v6n2p52

\begin{abstract}
Coal mining, open cast/ underground adversely affects the Eco-system. Raniganj area known as mining zone, but several time natural hazards (land subsidence) occurs in the area, Subsidence in old workings leads to severe damage to surface structures. It is very much important that suitable assessment studies to learn the potential adverse impact of mining on environmental ecosystem (flora, fauna). In the subsequent discussions an attempt has been made to clarify the coal mining activities and its outstanding impact on environment and agricultural activities. The study area region being the foremost coal producing region country, it's also ranked high in the list of environmentally degraded areas, in mining area have seen that waste materials are usually stacked as huge dumps in surroundings. After that those dumps were coupled with coal dumps, because this significant effect impact on land. The environmental awareness is given our society brought life from mining area another concerted effort for reclamation of the subsided land.
\end{abstract}

Keywords: mining, subsidence, cadastral, borehole, environment

\section{Introduction}

Raniganj coalfield, the birthplace of the Indian coal industry that ushered in coal mining activities in this country in the late eighteenth country, still holds a place of pride amongst the Indian coalfields being a storehouse of different types of coal. Raniganj is practically the sole repository of superior quality, high volatile, non coking coal, the resources of which are scanty in this country. The stupendous resource of solid fossil fuel had been the rich pasture for the fortune seekers dealing with this merchandise leading to the growth of mining industry vis-a-vis rapid industrialization of the country (Mondal et al, 2014). Cadastral provide the total assessment of land degradation recorded due to mining activity and its mitigation measures (Govind et al., 2013). This Paper focuses on the related issues in the rural areas of Raniganj coalfield of Barddhaman district. The investigation helps to take proper decisions based on the proposed model of analysis of the social and geo-environmental hazards associated with the different mining operations in the study area. Demarcation of subsidence area and their information using cadastral layout for supporting the borehole map have elevation, location with respect to geological condition of the study and finally land planning of mining area.

\section{Study Area}

The Gondwana basins of peninsular India, being generally restricted in the east-central part of our country, are disposed along well-defined linear belts of Damodar-Koel, Son-Mahanadi, Narmada and Pranhita-Godavari valleys besides the Rajmahal basin. Raniganj coalfield is the easternmost member of the Damodar-Koel valley basin belt. Its limits are bounded by the latitudes $23^{\circ} 22^{\prime}$ and $23^{\circ} 52^{\prime} \mathrm{N}$ and longitudes $86^{\circ} 30^{\prime} \mathrm{E}$ and $87^{0} 30^{\prime} \mathrm{E}$. This coalfield forms parts of Survey of India toposheet no. $73 \mathrm{M} / 2$. Figure 1 showing the location map of the study area. Raniganj area, geographically major portion of the coalfield area located in state of west Bengal, only the comparatively shallower northwestern part spilling over in state of Jharkhand. Lion's share of the West Bengal part covers part of Barddhaman district with the northern, southern and south-western fringe area falling in the districts of Birbhum, Bankura and Purulia respectively (Mondal et al, 2014).

The entire area covering Raniganj coalfield is very well connected. The main line of the eastern Railway, joining Kolkata and Delhi, traverses through the middle of the coalfield. Important railway stations and industrial towns 
on this line are Panagrarh, Durgapur, Andal, Raniganj and Asansol, Grand Trunk Road, National Highway No-2 connected Delhi with Kolkata, traverses through the coalfield running to the Grand Chord Line. The road passes through all the industrial townships mentioned above. Besides, a network of motor able roads connects various localities, collieries and factories. The natural topography, however, has been greatly defaced by the two century old mining activities, mostly along outcrop stretches of the coal-bearing formations (Sikder et al, 2004). A series parallel elongated lows and ridges have been carved out along the in crop regions of the thick coal seams due to open cast quarries and mine dumps (Coal Resources of West Bengal, 2003).

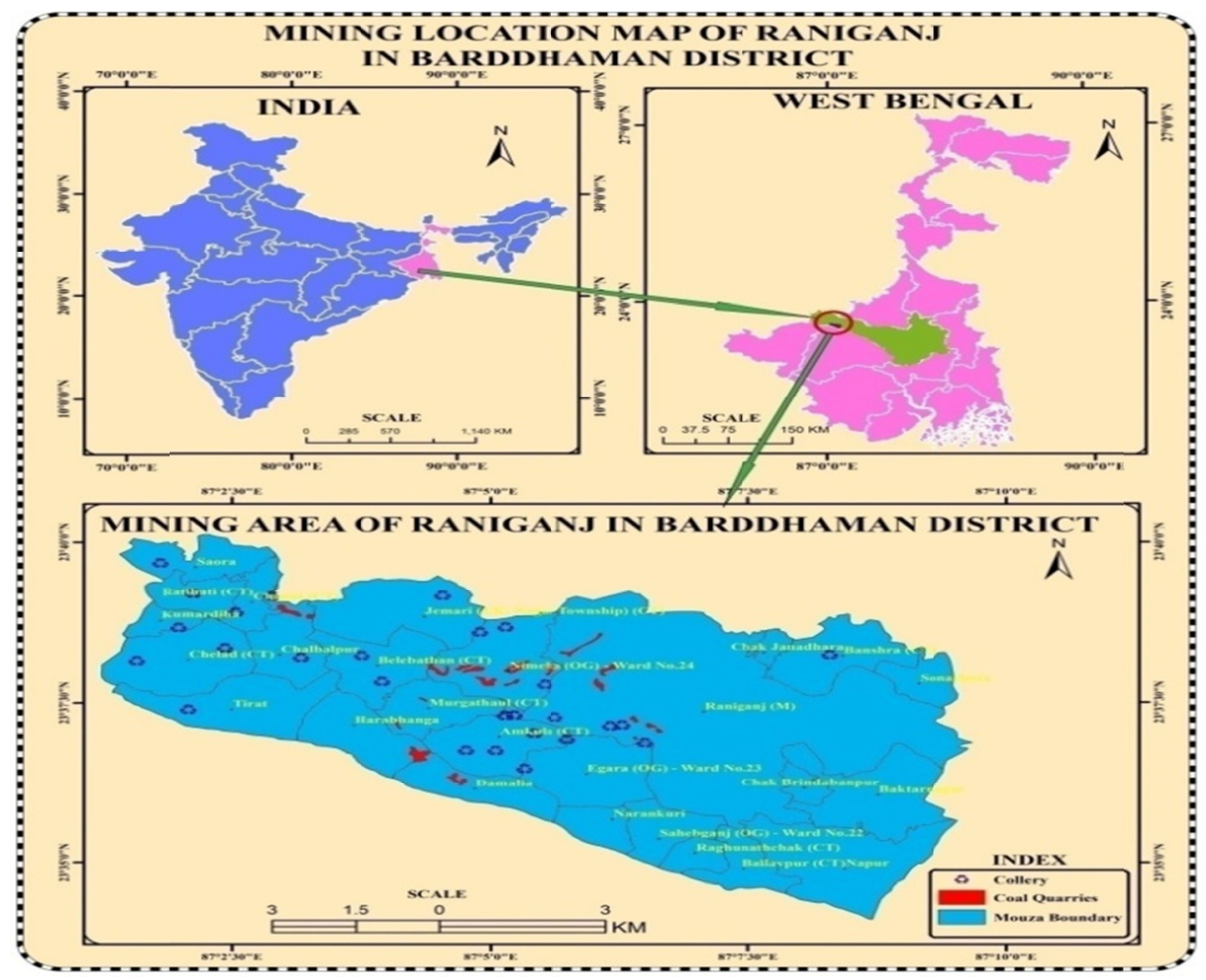

Figure 1. Location map of the study area

\section{Material and Methods}

\subsection{Drawbacks Bord and Pillar}

The bord and pillar mining, Mining have been removed from the bords, but about half of the coal is left undisturbed as pillars to support the roof. This method to open cast and underground mining, in residual subsidence can be the major subsidence measured on the surface of the earth. Even in will designed bord and pillar layout, additional weight transmitted to the pillars due to excavations will cause measurable deformation on the pillars and these movements will eventually be transmitted to the surface. Depending upon the extent of pillar loading and the characteristics of the pillars and the superincumbent material, the surface deflection may vary from considerable to negligible. All the studies dealt are the cases of bord and pillar workings.

\subsection{Pillar Stability Analysis}

In computing the factor of safety of the long standing/ supporting pillars, the following equations are used to estimate the pillar strength and load on pillars:

$$
\mathrm{S}=0.27 \boldsymbol{\sigma}_{\boldsymbol{c}} \mathrm{h}^{-0.36}+(\mathrm{H} / 250+1)\left(\mathrm{W}_{\mathrm{C}} / \mathrm{h}-1\right) \mathrm{MP}_{\mathrm{a}}
$$

Where, $\mathrm{S}$ is pillar strength, $\mathrm{MPa}, \sigma_{\mathrm{c}}$ is uniaxial compressive strength of 1 inch coal cube, $\mathrm{MPa}, \mathrm{H}$ is depth below surface, $\mathrm{m}, \mathrm{h}$ is working height, $\mathrm{m}$ and we is $2 \mathrm{w} 1 \mathrm{w} 2 /(\mathrm{w} 1+\mathrm{w} 2)=$ pillar width, $\mathrm{m}$

$$
\mathrm{P}=0.25 \mathrm{H}\left(\mathrm{L}_{1} \mathrm{~L}_{2}\right) / \mathrm{W}_{1} \mathrm{~W}_{2} \quad \mathrm{MP}_{\mathrm{a}}
$$

Where, $\mathrm{P}$ is load on pillar, $\mathrm{MP}_{\mathrm{a}} \mathrm{w}_{1}, \mathrm{w}_{2}$ is pillar width, $\mathrm{m}, \mathrm{H}$ is depth below surface, $\mathrm{m}, \mathrm{L}_{1} \mathrm{~L}_{2}$ is centre to centre pillar sizes, $\mathrm{m}$. this factor of safety is developed coal pillars without stowing should not be less than 2 whereas it should not be less than 1 in case of stowed developed coal pillars for the long term stability point of view. In this 
paper have taken this analyses and some formula (Prakash, et al. 2009).

\section{Result and discussion}

\subsection{Physiography of the Study Area}

The Barddhaman district has been divided into four distinct geomorphologic sectors west to east according to physiographic characteristic regionally

* Eastern fringe of Chotonagpur plateau tin to west/north west sector with erosion land forms

* Gondowana upland in the western part predominantly a coal mining belt.

* Dissected lateritic upland (upper \& lower) in the central part characterised by table land and associated with gently sloping terrain mainly forest land.

* Alluvial plan in the East and South West with depositional land forms specially exhibiting a fluvial fan of the Damodar river.

Soil type of this region is moderately well to well drained, loamy to fine loamy in the area, acidic in reaction. The north western part of the district characterised by gently undulating surface with enclosures of erosional remnants light residual hills and pediment etc. maithon is the highest point of the residual hill complex in the area. Chhotonagpur Granite Gneiss Complex in the north/ north western part of the district shows varying slops due to undulating nature of terrain.

Two types of soils have found in the Gondwana upland area i.e western part of the Barddhaman district, mainly coal mining belt area. In the coal belt reddish yellow to yellowish red sheletal soil (mainly plinthustalfs) and other part of dissected Gonduana upland are characterised by the presence of light olive brown to yellowish brown clayey.

The western part of district constitutes the Gonduana upland which is termed as upper plateau is highly dissected. But new part of Gondwana upland is relatively less dissected. The area exhibits various slope classes ranging from very gently sloping to very steep sloping. The characteristic of the area is largely obliterated by open cast as well as underground coal mining activities (District environmental Atlas, 2005).

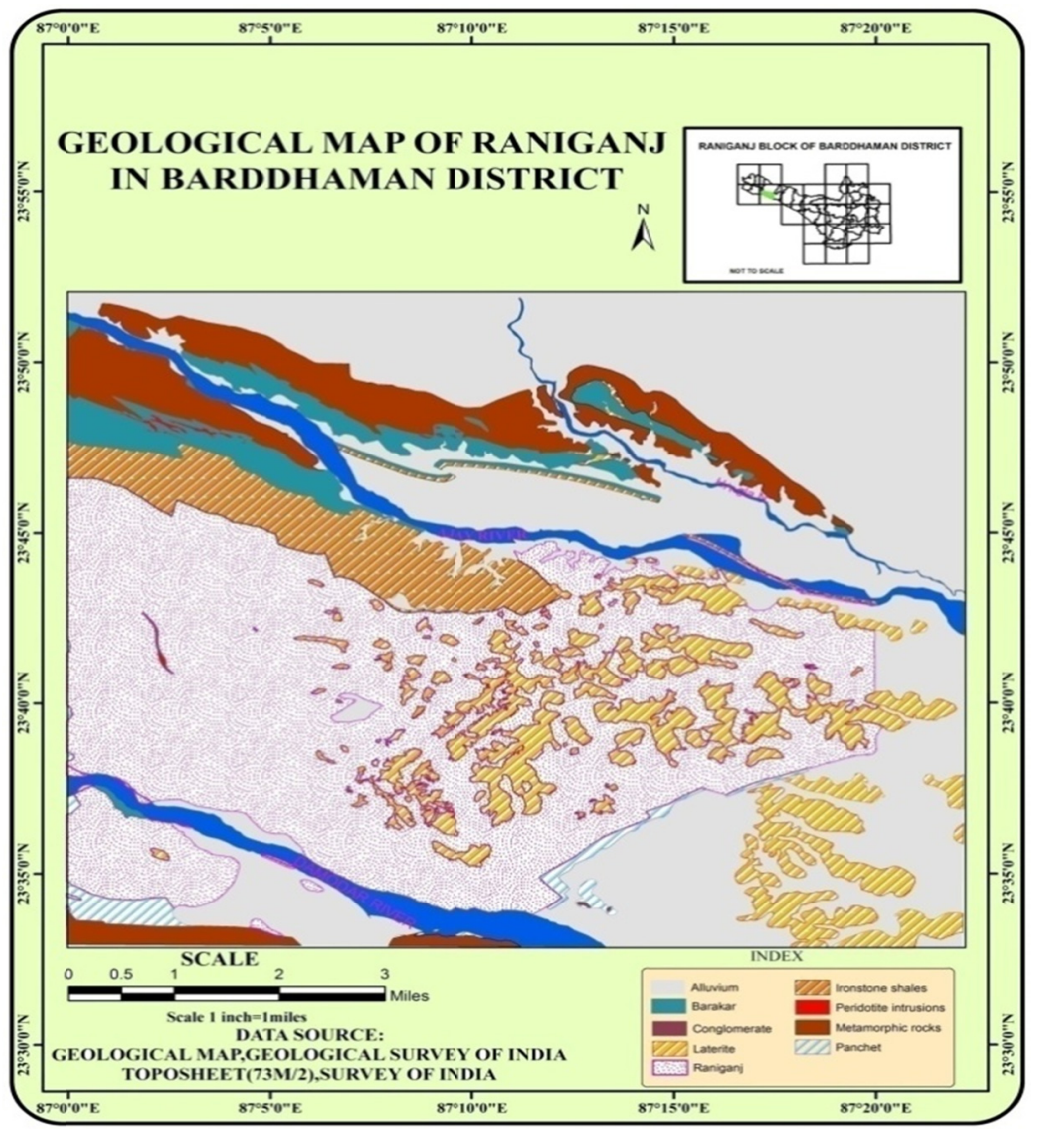

Figure 2. Geological map of the study area 


\section{Above the figure show that:}

Geological unit $=$ Gondowana Supergroup.

$$
\text { Age }=\text { Upper Permian }
$$

Lithology $=$ Sandstone $\&$ shale with coal

\section{Lateritic zone:}

$$
\begin{gathered}
\text { Geological unit }=\text { Dhalbhun gravel } \\
\text { Ager }=\text { Tertiary } \\
\text { Lithology }=\text { Lateritised peeldes }
\end{gathered}
$$$$
\text { Sijura/Rampurhat F-U.Pleistocen-E Holocen }
$$$$
\text { Lalgarh/illambazar F-Mid-U. Pleistocen }
$$$$
\text { Panchet F- Lr. Triassic }
$$$$
\text { Raniganj F-U.Permian }
$$
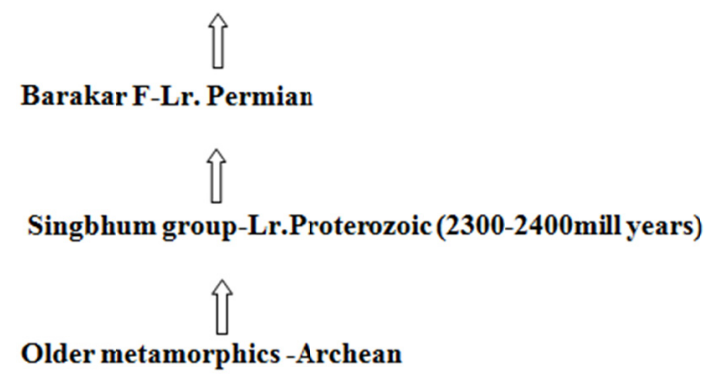

\subsection{Geological Condition of Raniganj Area}

There has not been any major change in the physical attributes of Lithological units, their contacts or subdivisions as enumerated by him. A very important addition is the recognition of volcanic activity in Raniganj coalfield area, which was hitherto unknown. The presence of Rahmahal volcanic and associated intertrappean sediments, overlying Panchet/supra panchet rocks and concealed below Tertiary sediments, has been established in the eastern fringe area.

Gondwana sedimentation in the Raniganj basin was ushered in by widespread deposition of glacial and peri glacial sediments of Talchir Formation. It was a general belief that the domain of Talchir sedimentation was somewhat restricted to the bed rock depressions mostly along the northern part of the coalfield.

The Telchir sediments have succeeded by a thick sequence of coal measures, which has been chosen as Barakar Formation. The existence of Karharbari Formation, however, is not very fit established in Raniganj coalfield. However, opined that the Karharbari rocks should be considered as a basal member of the Barakar Formation formula. Many a worker is of the view that no well-defined Karharbari horizon can be recognized here.

The Raniganj formation shows its acme of development in this basin and evidently, this coalfield or coal belt is the type area for the same. This formation, on account of greater thickness and gentle dips of beds, crop out over a wider area than the other formations. It shows a thicker development towards the western and central part of the coalfield where it attains $1150 \mathrm{~m}$ thickness and progressively decreases in thickness towards the east (Coal Resources of West Bengal, 2003).

The Barddhaman district is covered by alluvium expect in the Asansol subdivision where Gondwana rocks are exposed. The deposits which cover the immense alluvial plain of the Ganges and the Brahmaputra and their tributaries belong in part to an older alluvial formation, which is usually composed of massive argillaceous beds of a rather pale reddish-brown hue often weathering yellowish, disseminated throughout which occur kankar and 
pisolitic ferruginous concretions. The soil is partly Literite clay more or less altered and partly red colored coarse-grained sands, characteristic of the eastern ranges of the Vindhya formation, large surfaces composed of which are to be found in the beds of the Damodar and Ajoy Rivers (Peterson J.C.K., 1994).

Above the geological map show that, no of classes is given in the Raniganj area, there are allurium, Barakar, conglomerate, laterite, Ironstone shales, peridotite intrusions, metamorphic rocks and Punchet only, but the area is covered by laterite. Upper part have Ajay river and Hinga Nadi, and lower part have Damodar River, this data collatedfrom Geological survey of India.

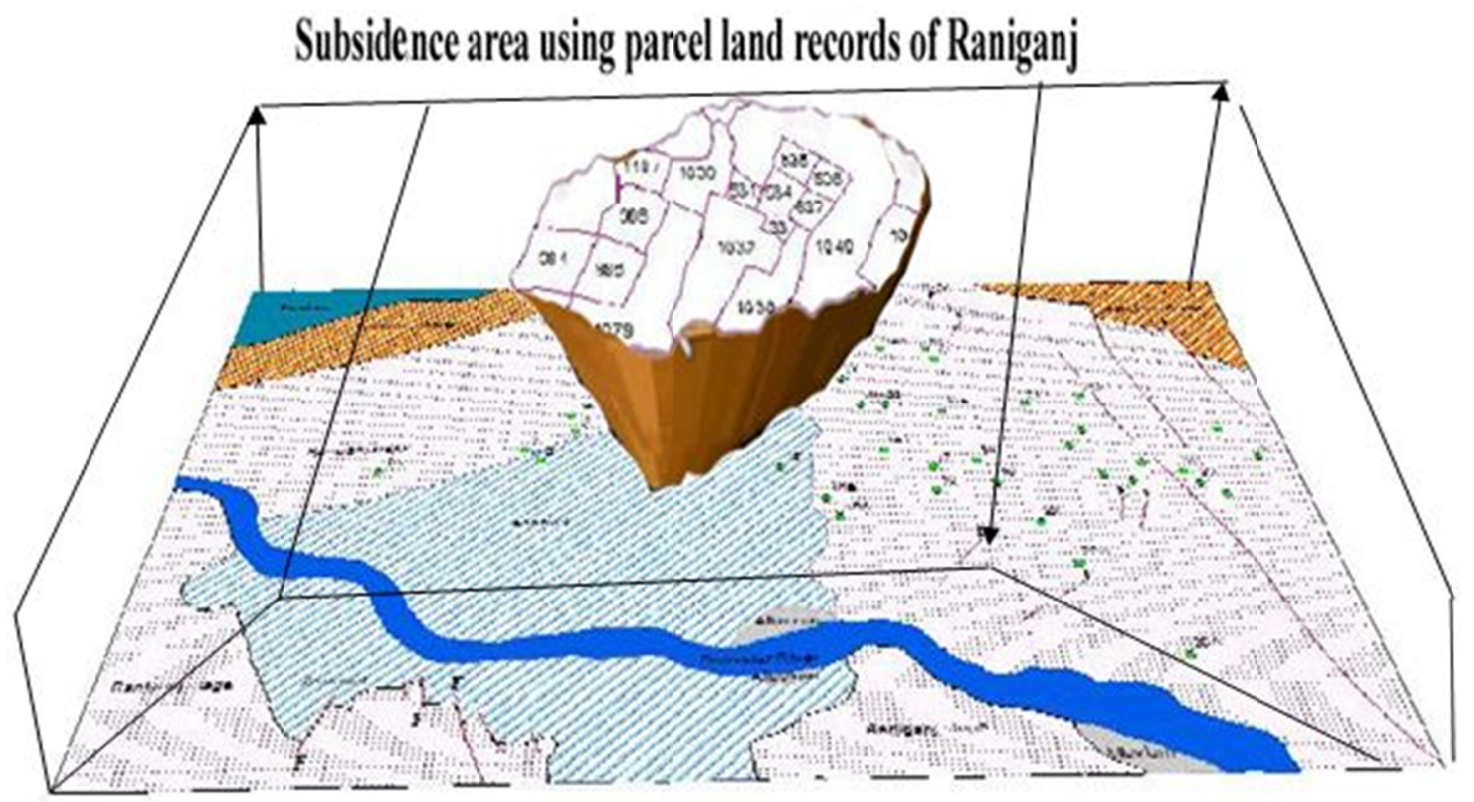

Figure 3. Percel/ plot wise land subsidence

\subsubsection{Cause of Subsidence in Mining Area}

1. Drowning of panel 2, old unstabilised roof falls along slip planes in 10 bottom and 10 kerridge sections at shallow depth below old surface subsidence aggravated the occurrence of recent surface subsidence. Dewatering also reduces the underground support several small pillars in 14 seam triggered the areal collapse as per low safety factors of small pillars, the rest of the seams being stable.

2. As these pillars were surrounded by goaves, the actual load acting on pillars would definitely be higher. Presence of fire was recorded in few boreholes. Safety factors of developed pillars were high for long term stability point of view. Subsidence was caused due to fire in top Disregard seam (Prakash, et al 2009).

\subsubsection{Structural Aspects of the Study}

Four sets of lineaments are identified from the imagery in the Gondwana Upland area from surface expression viz 1) NNW-SSE, 2) NW-SE, 3) NNE- SSW and 4) ENE-WSW. These lineaments show intimate interrelationships with the strike and dip directions of the already established faults associated with Gondwana Super group.

The southern and eastern margin of the Gondwana basin is faulted against the basement ridges. These basin margin faults striking NNW-SSE with steep dip due east sharply terminated the Gondwanas, may be one such surface expression of the fault. It is interesting to mention that some of the NNW-SSE/NW-SE lineaments may be considered as deep seated faults which play a facilitator role in 'earth degassing' in terms of migration of non atmospheric Helium from the mantle beneath around Shyamla,Kendra khottadi and Mahira.

\subsubsection{Wastern Coal Belt}

The western part of the study area, the coal mining area has its own unique problem of land subsidence, land degradation irregularities in depth to ground water table and subsurface coal mine fire supporting document bore hole map in above the area. The areas of land subsidence could easily be identified in the imagery from the 'geomorphic anomalies' as well as Drainage Deflections/ anomalies.

In the present day context of environmental consideration in coal mining areas, especially, in open cast mining 
(OCM) areas, land degradation have come into sharp focus It is well established fact that the removal of vegetation, top soil and waste dumps of OCM or underground mining, change the original topographic/ landform features as well as hydrological condition.

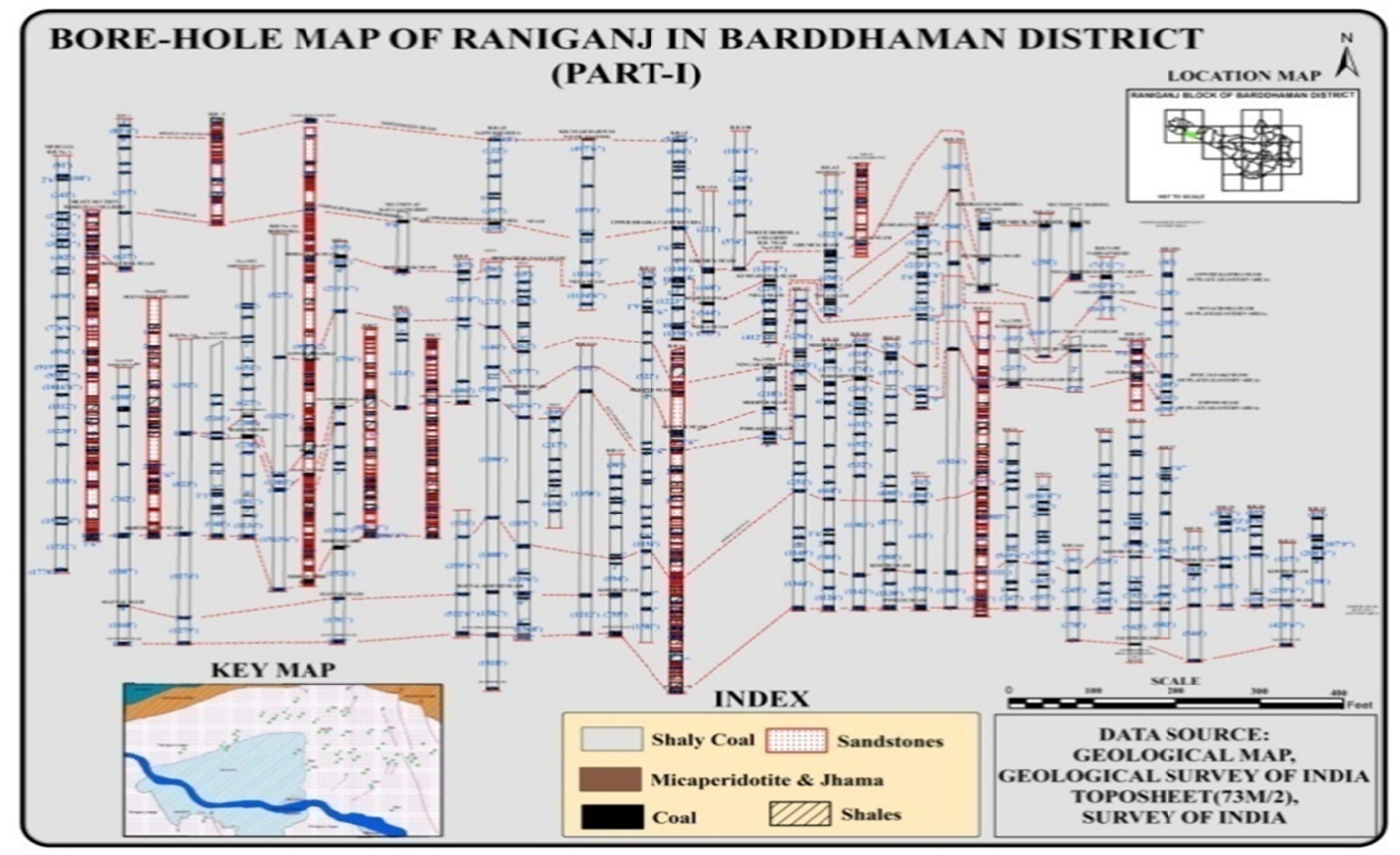

Figure 4. Bore hole map of the study area

It may be electronically generated from the properties of the rocks by lowering instruments down the bore. Providing site-specific information that can help determine the geology and nature of the ground and it can help to identify any apparent or potential Hazards related issue. Above the map provide five classes like shaly coal, Micaperidotite \& Jhama, coal, sandstones, and shales, Boreholes provide one of the most important sources of information available on the geological structure and also sub-surface mining area. The most common shallow boreholes are drilled for construction work and provide alarge amount of the information which we base our interpretation of the geology and it basis for our surveying work, analysis this thickness has been estimated that we have planed, need this information to carry out our surveying related work Borehole records save time and money by allowing.

Companies to design their surveys and construction work properly above the area. Exploration companies can use existing information to try to predict the presence of ore bodies and hydrocarbons, for example. Mining related Materials collected from boreholes can be used to Corroborate the written record also, and its further analysis testing. If borehole material has been stored appropriately its properties do not change significantly with time respectively and it can be re-analyzed for other purposes in the area (report on National Geological Records Centre).

Bore holes are mainly made for the survey of different economically viable minerals and coal. Bore hole provide to specific information in bellow

$>$ Soil conditions - for construction

$>$ Engineering properties like - physical and chemical condition

$>$ Contamination - natural \& man-made

$>$ Geology condition

$>$ Shell and auger drilling related

$>$ Structure base

$>$ Mining activity - deep \& shallow related

$>$ The presence of natural cavities

$>$ Presence of minerals -coal, oil, sand, gravel gypsum etc. 
$>$ Presence of water and monitoring its availability condition

$>$ Hazards- finding presence or alleviation.

Table 1. Borehole location and elevation

\begin{tabular}{|c|c|c|c|c|c|c|c|}
\hline Bore Hole No. & Latitude & Longitude & $\begin{array}{c}\text { Elevation }(\mathrm{F} \\
\text { eet })\end{array}$ & $\begin{array}{l}\text { Bore } \\
\text { Hole No. }\end{array}$ & Latitude & Longitude & Elevation(Feet) \\
\hline 33 & $23.40^{\prime} 51.792 " \mathrm{~N}$ & 87.7'12.626"E & 6.66 & $54 \mathrm{~A}$ & $23.39^{\prime} 26.327 " \mathrm{~N}$ & 87.16'15.736"E & 4.43 \\
\hline 34 & $23.40 ' 2.452 " \mathrm{~N}$ & 87.7'58.472"E & 10.77 & $54 \mathrm{~B}$ & $23.39^{\prime} 17.975^{\prime \prime} \mathrm{N}$ & 87.16'18.092"Е & 7.3 \\
\hline 35 & $23.35^{\prime} 56.383 " \mathrm{~N}$ & 87.10'48.611"E & 6.71 & $54 \mathrm{C}$ & $23.39^{\prime} 22.687^{\prime \prime} \mathrm{N}$ & 87.16'38.864"E & 7.07 \\
\hline $35 \mathrm{~A}$ & $23.35^{\prime} 55.098^{\prime \prime} \mathrm{N}$ & $87.10^{\prime} 33.963 " \mathrm{E}$ & 6.56 & $54 \mathrm{D}$ & $23.39 ' 3.841 " \mathrm{~N}$ & 87.16'14.879"E & 5.14 \\
\hline $35 \mathrm{~B}$ & $23.35^{\prime} 18.864 " \mathrm{~N}$ & $87.10^{\prime 2} 27.538 " \mathrm{E}$ & 6.53 & 55 & $23.38^{\prime} 23.795^{\prime \prime} \mathrm{N}$ & 87.16'7.598"E & 8.47 \\
\hline 36 & $23.36^{\prime} 14.629 " \mathrm{~N}$ & 87.9'55.929"E & 24.83 & $55 \mathrm{~A}$ & $23.38^{\prime} 47.566^{\prime \prime} \mathrm{N}$ & 87.17'7.775"E & 8.03 \\
\hline $36 \mathrm{~A}$ & $23.36 ' 39.299 " \mathrm{~N}$ & 87.9'51.304"E & 5.55 & 56 & $23.41 ' 53.664 " \mathrm{~N}$ & 87.16'7.384"E & 12.43 \\
\hline $36 \mathrm{~B}$ & $23.36^{\prime} 12.573 " \mathrm{~N}$ & 87.9'15.326"Е & 6.82 & 57 & $87^{\circ} 11^{\prime} 28.148^{\prime \prime E}$ & $23^{\circ} 41^{\prime} 43.107^{\prime \prime} \mathrm{N}$ & 2.83 \\
\hline 37 & $23.36 ' 8.461 " \mathrm{~N}$ & 87.10'5.695"E & 11.4 & 58 & 23.38'9.019"N & 87.15'6.993"E & 7.81 \\
\hline 38 & $23.35^{\prime} 44.814^{\prime \prime} \mathrm{N}$ & 87.11'41.408"E & 7.15 & 59 & $23.42^{\prime} 56.838^{\prime \prime} \mathrm{N}$ & 87.16'45.503"Е & 8.14 \\
\hline $38 \mathrm{~A}$ & $23.35^{\prime} 19.973 " \mathrm{~N}$ & 87.12'11.817"E & 16.28 & 60 & $23.38^{\prime} 36.002 " \mathrm{~N}$ & 87.17'9.916"Е & 11.23 \\
\hline $38 \mathrm{~B}$ & $23.34 ' 58.558 " \mathrm{~N}$ & 87.11'12.497"E & 7.89 & 61 & $23.42^{\prime} 29.855^{\prime \prime} \mathrm{N}$ & 87.16'58.78"E & 8.28 \\
\hline 39 & $23.37^{\prime} 39.68 " \mathrm{~N}$ & $87.11^{\prime} 4.788^{\prime \prime} \mathrm{E}$ & 13.34 & $61 \mathrm{~A}$ & $23.42^{\prime} 22.146 " \mathrm{~N}$ & 87.17'30.261"E & 7.97 \\
\hline 40 & $23.37 ' 33.684 " \mathrm{~N}$ & $87.12^{\prime} 0.681 " \mathrm{E}$ & 6.4 & 62 & $23.41^{\prime} 47.025 " \mathrm{~N}$ & 87.16'26.872"E & 6.23 \\
\hline 41 & $23.38^{\prime} 4.522 " \mathrm{~N}$ & 87.11'51.473"E & 8.57 & 64 & $87^{\circ} 16^{\prime} 42.95 " \mathrm{E}$ & $23^{\circ} 41^{\prime} 15.866^{\prime \prime} \mathrm{N}$ & 5.39 \\
\hline 42 & $23.37 ' 57.026 " \mathrm{~N}$ & 87.12'9.033"E & 5.56 & 65 & $23.41 ' 32.891 " \mathrm{~N}$ & 87.17'57.029"E & 8.87 \\
\hline 43 & $23.38^{\prime} 46.924 " \mathrm{~N}$ & 87.12'33.661"E & 9.04 & $65 \mathrm{~A}$ & $23.41 ' 29.679 \mathrm{~N}$ & 87.18'39.431"Е & 6.24 \\
\hline $43 \mathrm{~A}$ & $23.39^{\prime} 13.478^{\prime \prime} \mathrm{N}$ & 87.12'6.892"E & 5.35 & $65 \mathrm{~B}$ & $23.41^{\prime} 17.044 " \mathrm{~N}$ & 87.19'13.696"E & 7.65 \\
\hline 44 & $23.38^{\prime} 51.635^{\prime \prime} \mathrm{N}$ & 87.12'47.366"E & 6.59 & 66 & $23.42^{\prime} 48.272 " \mathrm{~N}$ & 87.17'9.916"E & 6.93 \\
\hline 45 & $87^{\circ} 9^{\prime} 48.696^{\prime \prime} \mathrm{E}$ & $23^{\circ} 38^{\prime} 24.46 " \mathrm{~N}$ & 17.74 & $66 \mathrm{~A}$ & $23.42^{\prime} 38.421 " \mathrm{~N}$ & 87.17'36.257"Е & 1.7 \\
\hline $45 \mathrm{~A}$ & $87^{\circ} 10^{\prime} 23.131^{\prime \prime} \mathrm{E}$ & $23^{\circ} 38^{\prime} 34.739^{\prime \prime} \mathrm{N}$ & 4.22 & 67 & $23.43^{\prime} 10.116^{\prime \prime} \mathrm{N}$ & 87.17'7.132"E & 6.61 \\
\hline $45 \mathrm{~B}$ & $23.38^{\prime} 40.746 " \mathrm{~N}$ & 87.11'24.862"E & 2.73 & 68 & $23.43^{\prime} 7.332^{\prime \prime} \mathrm{N}$ & 87.16'58.352"E & 10.2 \\
\hline 46 & $87^{\circ} 9^{\prime} 45.612^{\prime \prime} \mathrm{E}$ & $23^{\circ} 38^{\prime} 56.839^{\prime \prime} \mathrm{N}$ & 15.22 & 69 & $23.43^{\prime} 55.203 " \mathrm{~N}$ & 87.14'41.595"E & 9.78 \\
\hline $44 \mathrm{~A}$ & $23.38^{\prime} 53.991 " \mathrm{~N}$ & 87.13'31.696"E & 7.82 & $69 \mathrm{~A}$ & $23.43^{\prime} 49.241^{\prime \prime} \mathrm{N}$ & 87.13'46.704"E & 4.93 \\
\hline $44 \mathrm{~B}$ & $23.39^{\prime} 0.201 " \mathrm{~N}$ & 87.13'40.69"E & 3 & 70 & $\begin{array}{l}23.43^{\prime} 37.112 " \mathrm{~N} \\
\text { DATA IS NOT }\end{array}$ & 87.16'54.404"E & 6.22 \\
\hline 47 & $87^{\circ} 13^{\prime} 23.018^{\prime \prime} \mathrm{E}$ & $23^{\circ} 37^{\prime} 43.856^{\prime \prime} \mathrm{N}$ & 6.78 & 63 & AVABILABLE & 9.69 & \\
\hline $47 \mathrm{~A}$ & $87^{\circ} 13^{\prime} 38.437^{\prime \prime} \mathrm{E}$ & $23^{\circ} 37^{\prime} 46.426^{\prime \prime} \mathrm{N}$ & 9.64 & \multicolumn{3}{|c|}{ BORE HOLE PART-I } & \\
\hline 48 & $23.40^{\prime} 3.376 " \mathrm{~N}$ & 87.11'24.862"E & 5.82 & & & & \\
\hline 49 & $23.40^{\prime} 48.347 " \mathrm{~N}$ & 87.13'49.256"Е & 3.64 & & & & \\
\hline $49 \mathrm{~A}$ & $23.40^{\prime} 48.776 " \mathrm{~N}$ & 87.12'10.532"Е & 6.51 & & & & \\
\hline 50 & $23.37 ' 8.548 " \mathrm{~N}$ & 87.13'34.694"E & 6.62 & & & & \\
\hline $50 \mathrm{~A}$ & $23.37 ' 23.11 " \mathrm{~N}$ & 87.13'32.338"E & 5.49 & & & & \\
\hline $50 \mathrm{~B}$ & $23.36 ' 36.425^{\prime \prime} \mathrm{N}$ & 87.13'8.567"E & 11.53 & & & & \\
\hline 51 & $23.39^{\prime} 35.322^{\prime \prime} \mathrm{N}$ & 87.14'3.604"E & 5.5 & & & & \\
\hline 52 & $23.40^{\prime} 15.796 " \mathrm{~N}$ & 87.14'23.735"Е & 3.03 & & & & \\
\hline 53 & $23.35 ' 29.61 " \mathrm{~N}$ & 87.13'45.501"E & 8.43 & & & & \\
\hline $53 \mathrm{~A}$ & $23.36^{\prime} 10.298^{\prime \prime} \mathrm{N}$ & 87.13'15.306"Е & 11.62 & & & & \\
\hline $53 \mathrm{~B}$ & $23.36 ' 22.291 " \mathrm{~N}$ & 87.12'45.011"E & 10.45 & & & & \\
\hline
\end{tabular}

The Drilling work and sampling materials and information from boreholes its making an accurate record is very much expensive. However it is expensive to keep and store that information. Above the table show that present location and their elevation have given which help us to provide boro hole location and how much depth from the upper layer that will keep all site investigation reports in their entirety and any Individual borehole or geophysical records. it also keeps other relevant information such as photographs and video recordings etc. We will accept and keep digital, we have store selected core and sample material in the National Geological Material Collection. 


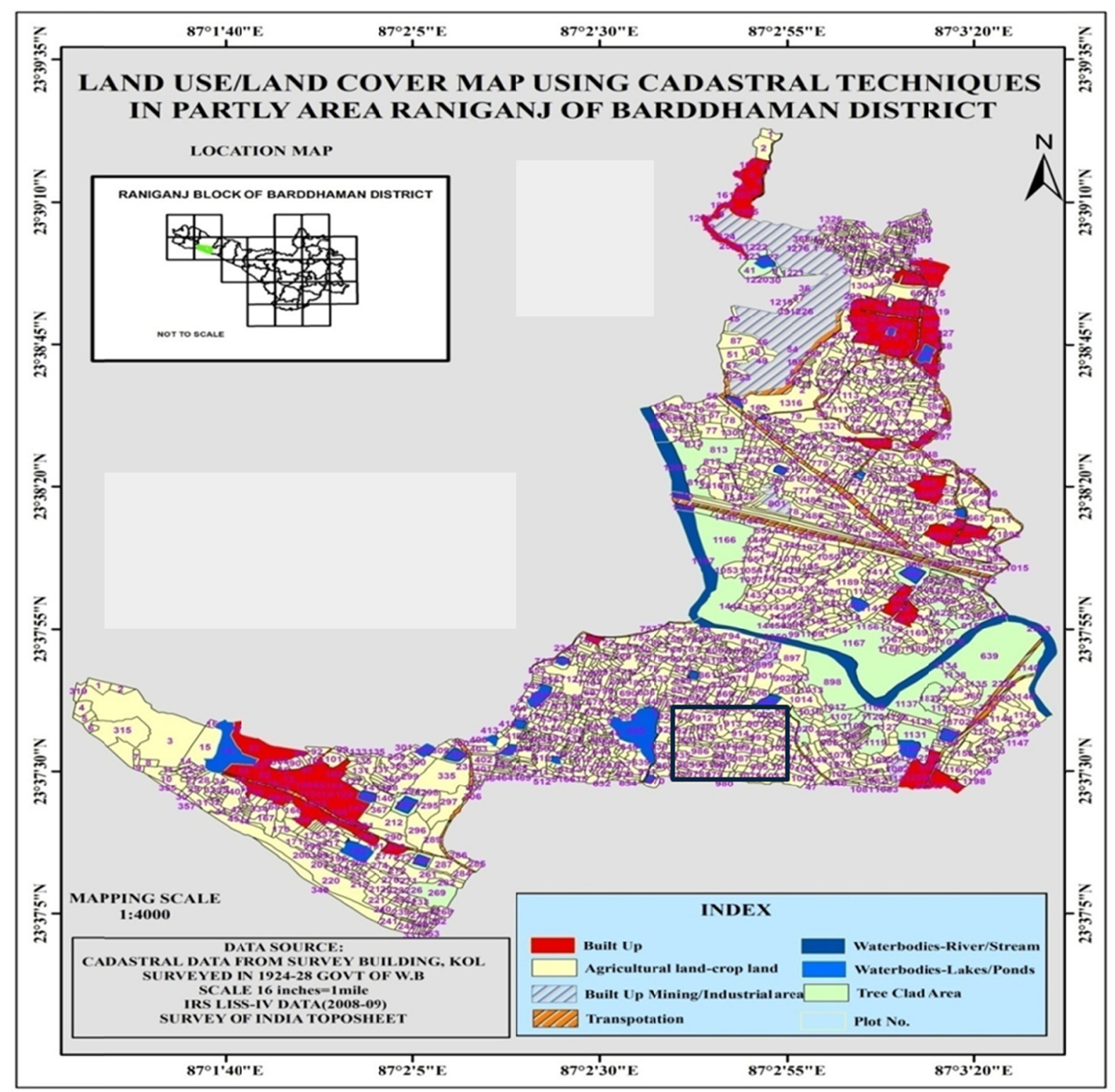

Figure 5. Land use/land cover map

A cadastral map will show the boundaries of land parcels but may also incorporate details of the resources associated with them, including the physical structures on or beneath them, their geology, soils, and vegetation and the manner in which the land is used above the map cadastral map given us to all details information which have located in rural area of Raniganj in Barddhaman district. Cadastre system have carry out some works to transform the current cadastre bases into the digital form in national coordinate system using cadastral data digitized on maps. But these digitized and transformed data caused very important boundary problems is high and structuring is dense.

The principal responsibility of the assessor is to locate, inventory, and appraise all property within the jurisdiction. A complete set of maps is necessary to perform this function. Maps help determine the location of property, indicate the size and shape of each parcel and reveal geographic relationships that affect property value. Maps and map data are important not only for assessors, but also for other governmental agencies, the public at large, and the land information community (such as realtors, title companies, and surveyors). In addition, the assessor must track current ownership of all parcels, so that the proper party can receive assessment notices and tax bills. 

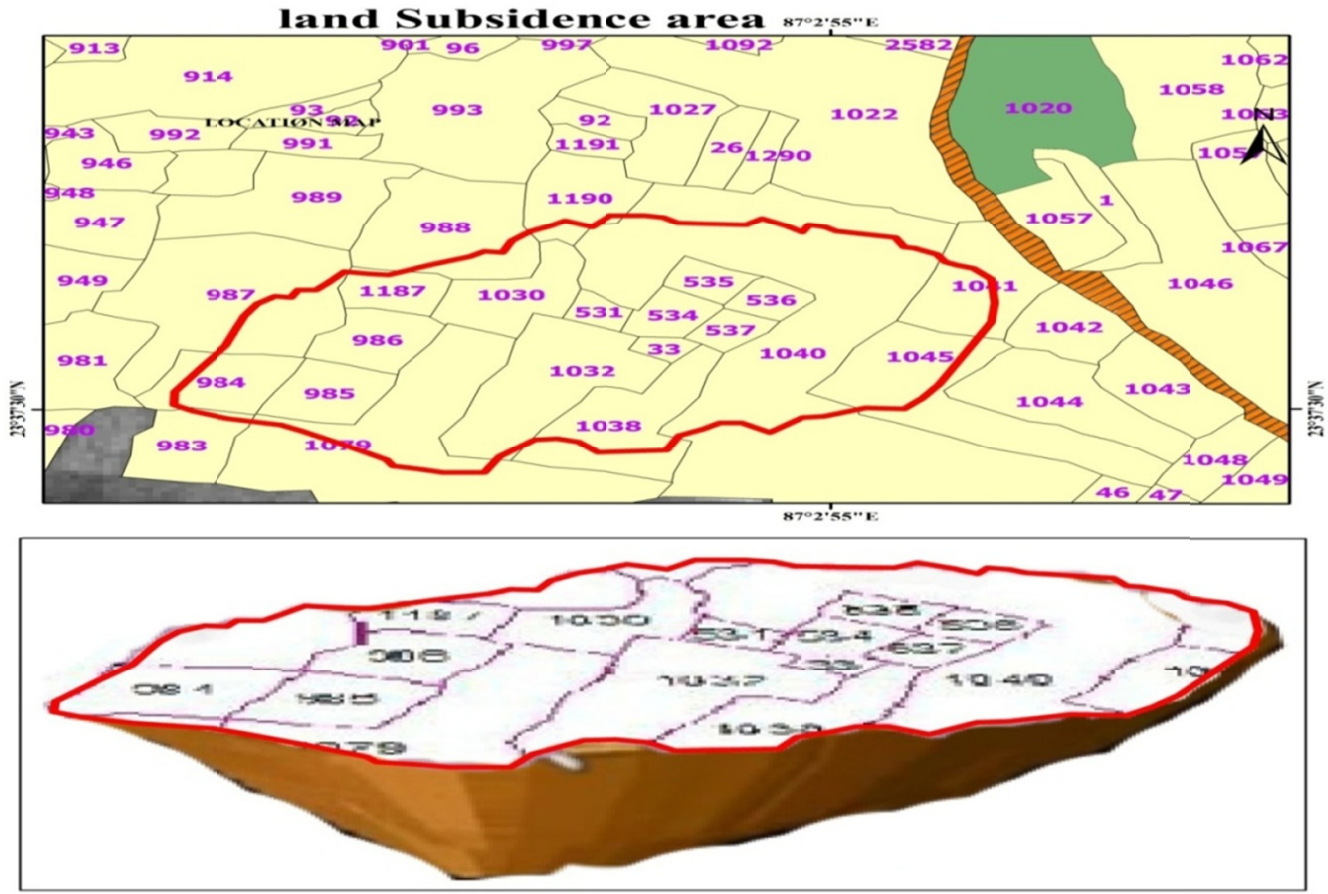

Figure 6. Subsidence area and plot No.

Above the analysis show that the no. of parcel are subsidence, using cadastral techniques are measured that present status of upper surface of land with Dag/Bata no. using cadastral land recorded help us to provide parcel information cum geological condition that we are planning risky zone of subsidence. Figure 7 represented that 984, 985, 986, 1187, 1030, 533, 531, 533. 537. 638, 1040, 1041, and 1045 those Dag/Bata no are subsidence. This technique is applicable for deserter management. Subsidence, tilt, horizontal displacement, curvature and strain are the parameters normally used to define the extent of the surface movement when lower part has vertically rotted. They generally form the basis for assessing the effects of subsidence on surface infrastructure. Mining can result in a shallow flat-bottomed rectangular trough at the surface, these effects can impact built environments issue and it such as roads and buildings as well as the cause disturbances one side of river courses and other side of surface water features.
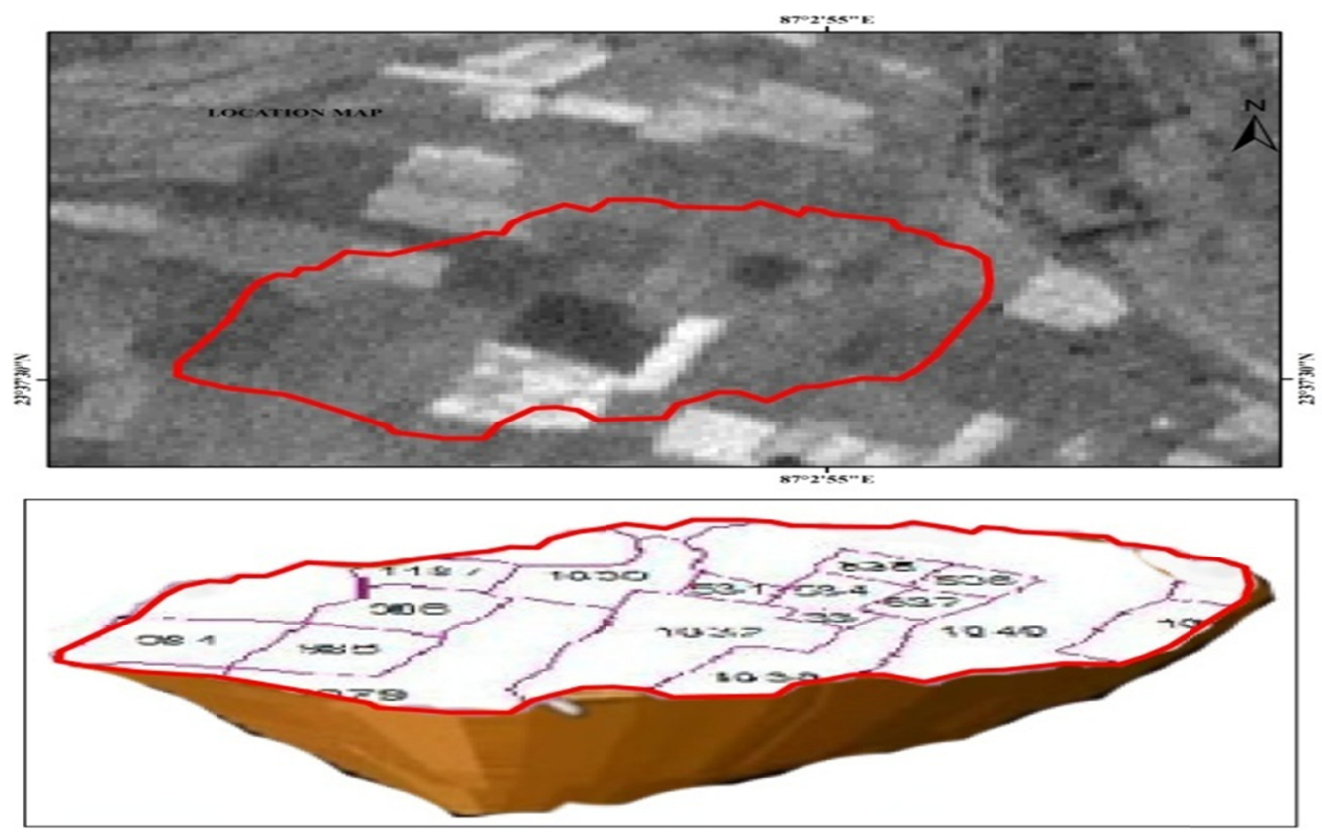

Figure 7. Satellite imagery and subsidence area 


\section{Conclusion}

If we predicting that mining area have subsidence due to poor underground condition (figure: 4 , bore hole map and Figure 2, geological map), industrial does not fulfill the sufficient sand in the mining area, it important parameter to procreate the subsidence. The general behavior of the rock mass in the area of long wall underground coal mining which initiates mine subsidence and surface ground movements is well recognized. The real behavior varies on a site-by-site basis in particular area, subsidence from coal mining activities depth of the mine, the amount of coal extracted from the mining zone related to geological, topographical factors. Above study area the Suitable methods and models are available for subsidence prediction, including a diversity of empirical, analytical and also numerical methods. This relies on initial monitoring at a mining area during the early stages of mining and is generally the most reliable of the various applicable methods. Subsequent area has development due to site-specific parameters to model. The predict subsidence during its expansion can support the initial prediction applicable in Incremental Profile Method. Suitable satellite technology or advance technology have available for measuring and monitoring the scale and extent of coal mining-induced subsidence in ground movements of natural hazards. Techniques include ground trouth surveys, airborne, Global Positioning System (GPS) and satellite-based remote sensing techniques. Overall, ground survey using GPS is the most common technique which used to monitor subsidence. Recently Advance technology like remote sensing or space technology techniques Light Detection and Ranging (LiDAR) are becoming an increasingly accurate, subsidence impacts are site-site specific zone, its significant feature that has the potential was affected by subsidence desires to be subjected to its own risk zone /impact assessment in the mining area. Impacts have to be managed by any one or more of the following:

- Tolerance of the resultant impact, natural processes of remediation activity.

- Avoidance measures; for example, barriers or buffers between panel extraction

- Significant features or modification of the mining system or geometry mitigation measures; for example, smaller buffers designed to reduce but not eliminate;

- Subsidence impacts, mine layout or system changes and use of slots to isolate ground movement from features or structures remediation or rehabilitation measures; for example, grouting or filling of surface.

- Subsurface cracks, drainage of ponded areas and revegetation of eroding areas.

Subsidence minimization, by retaining pillars of coal to support the overlying strata, has been practiced for a very long time. Pillar design is now supplemented by more intensive geological investigations, rock mechanic testing and numerical modeling of alternative mining layouts and dimensions. Methods to prevent subsidence include backfilling of the void to support the roof strata and artificial pillars to support the roof. However, these are impractical and rarely used. Grouting to infill surface cracking has been used with variable success (Subsidence from coal mining activities report 2014).

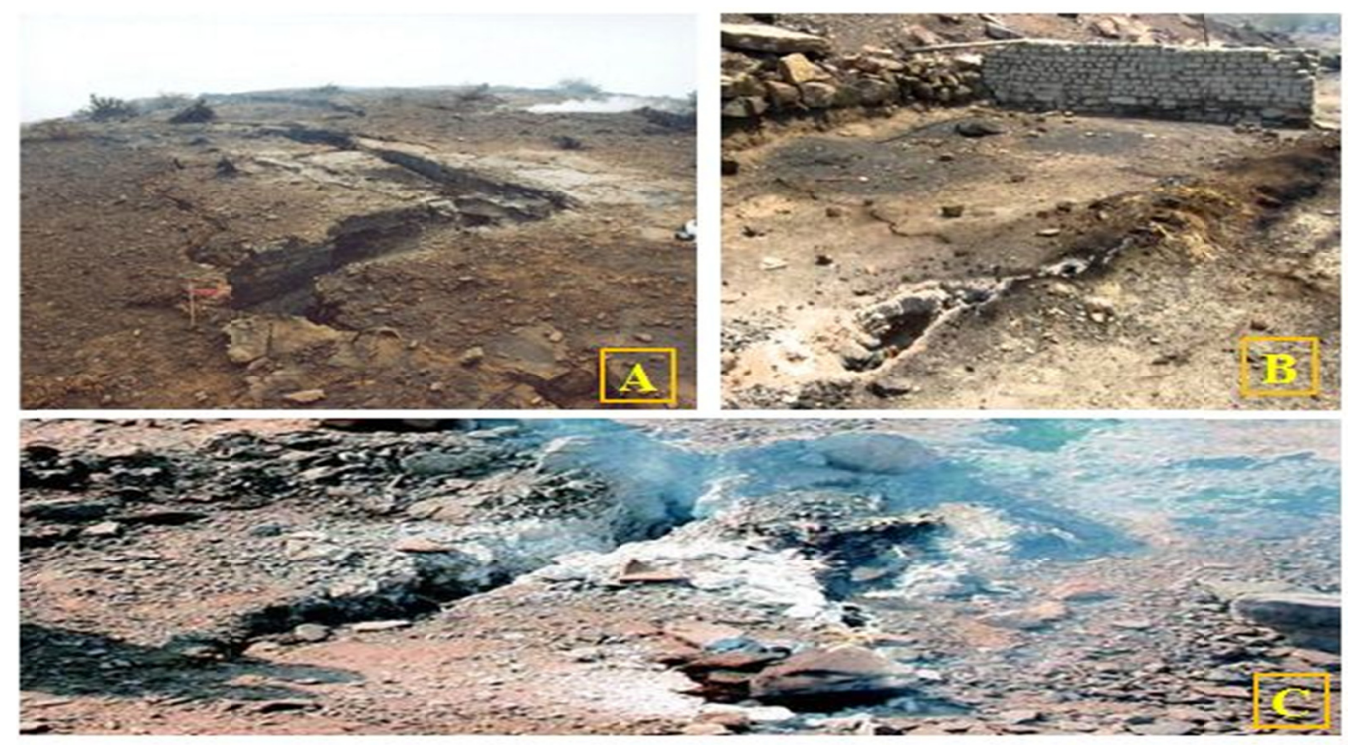

Figure 8. Field photographs of subsidence area in Raniganj area. 


\section{Reference}

Bandopadhyay, S. (2014). Crucial Factors Influencing Environmental Degradation: A Case Study on Raniganj Coal Mine Belt, West-Bengal India. International Journal of Engineering Development and Research, 3(1). ISSN: 2321-9939, pp 70-73.

Bauer, RA. (2008). Planned Coal Mine Subsidence in Illinois: A Public Information Booklet. Illinois Department of Natural Resources Illinois State Geological Survey.

Coal Resources of West Bengal (2003).

District Census Handbook (1991).

District Statistical Handbook (2000).

Gangopadhyay, K.P. et al. (2005). Application of remote sensing to identify coal fires in the Raniganj Coal belt, India. International Journal of Applied Earth Observation and Geoinformation, 1-8

Geological Survey circular 876 Report, (1983). Subsidence from Underground Mining: Environmental Analysis and Planning Considerations. https://pubs.usgs.gov/circ/1983/0876/report.pdf

Goswami, S. (2013). Environment Management in Mining Areas(A Study of Raniganj and Jharia Coal Field in India).Global Journal of Human Social Science(B), XIII(VII). Online ISSN: 2249-460X \& Print ISSN: 0975-587X. pp 11-20.

Goswami, S. (2013).Challenges of Environmental Management in Indian Coal Mining Sector.Universal Journal of Environmental Research and Technology, 3(6), 616-629

Govind, V.V.K., Reddy, K.V., Pratap, D., (2013). Updation of cadastral maps using high resolution remotely sensed, International Journal of Engineering and Advanced Technology (IJEAT) ISSN: 2249-8958, Volume-2, Issue-4, April.

Goswami, S., \& Goswami, R. (2014). Coal Mining vis-à-vis Agriculture in India: A question of Sustainability. International Research Journal of Geology and Mining (IRJGM) (2276-6618), 4(6), 154-162.

Introduction to Longwall Mining and Subsidence Report. (2007). Mine Subsidence Engineering Consultants.

Mondal, S., Chakravarty, D., Bandyopadhyay, J., (2014). Cadastral Maps for Socio-Economic Data Visualization and Integration for Land Use in Raniganj Mining Areas. International Refereed Journal of Engineering and Science (IRJES) ISSN (Online) 2319-183X, (Print) 2319-1821 Volume 3, Issue 10 ,October, 55-63.

National Geological Records Centre (NGRC) report.

Ojigi,L.M. (2011). Cadastral Layout Review and Re-Design of Jikpan Area of Minna Using High Resolution Imagery and Land Information System.

Peterson J.C.K., (1994) Bengal District Gazetteers hand book in burdwan.

Prakash, A., Lokhande, R.D., Singh K.B. (2009). Surface Ground Deformation in Jharia and Raniganj Coalfields Over Old Mine Workings. Indian J. Environmental Protection, 29(4).pp 289-294.

Roy, K.S. et al. (2002). Final report on regional exploration for coal in Churulia Sector,Raniganj Coalfield, Barddhaman District, West Bengal, Rep. GSI.

Report on Subsidence from coal mining activities, (2014). department of environmental, government of Australian.

Standard on Manual Cadastral Maps and Parcel Identifiers (2004).

Sikdar, K.P. et at. (2004). Land Use/Land Cover Changes and Groundwater Potential Zoning in and around Raniganj coal mining area, Barddhaman District, west Bengal - A GIS and Remote Sensing Approach. Journal of Spatial Hydrology, 4(2), 1-24.

\section{Copyrights}

Copyright for this article is retained by the author(s), with first publication rights granted to the journal.

This is an open-access article distributed under the terms and conditions of the Creative Commons Attribution license (http://creativecommons.org/licenses/by/4.0/). 